\title{
Effect of Staining and Aging on Translucency Parameter of CAD-CAM Materials
}

\section{Učinak bojenja i starenja na parametar translucencije CAD/CAM materijala}

\footnotetext{
${ }^{1}$ Department of Dental Materials and Prosthodontics, State University of Sao Paulo School of Dentistry at Sao Jose dos Campos, Sao Jose dos Campos, Brazil and Houston Center for Biomaterials and Biomimetics (HCBB), University of Texas School of Dentistry at Houston, Houston, TX Odjel za dentalne materijale i protetiku Stomatološkog fakulteta Državnoga sveučilišta u Sao Paulu pri Sao Jose dos Camposu, Sao Jose dos Campos, Brazil i Centar za biomaterijale i biomimetiku u Houstonu (HCBB), Stomatološki fakultet Sveučilišta u Houstonu, Houston, Teksas, $S A D$

2 Department of Prosthodontics, School of Dental Medicine, University of Belgrade, Belgrade, Serbia

Zavod za protetiku Stomatološkog fakulteta Sveučilišta u Beogradu, Srbija

3 Private practice, Belgrade and Houston Center for Biomaterials and Biomimetics (HCBB), University of Texas School of Dentistry at Houston, Houston, TX

Privatna ordinacija u Beogradu i Centar za biomaterijale i biomimetiku u Houstonu (HCBB), Stomatološki fakultet Sveučilišta u Houstonu, Houston, Teksas, SAD

${ }^{4}$ Division of Fixed Prosthodontics and Biomaterials, University of Geneva, Geneva, Switzerland

Zavod za fiksnu protetiku i biomaterijale Sveučilišta u Ženevi, Švicarska

${ }^{5}$ Department of Restorative Dentistry and Prosthodontics and Houston Center for Biomaterials and Biomimetics (HCBB), University of Texas School of Dentistry at Houston, Houston, TX

Odjel za restaurativnu stomatologiju i protetiku, Centar za biomaterijale i biomimetiku u Houstonu (HCBB), Stomatološki fakultet Sveučilišto u Houstonu, Houston, Teksas, SAD
}

\section{Abstract}

Objectives: To evaluate different intervals of exposure to staining solutions and artificial aging on translucency parameter (TP ${ }_{0}$ ) of CAD-CAM materials. Material and Methods: One millimeter thick square-shaped specimens $(\mathrm{N}=288)$ were cut from Cerasmart $(\mathrm{CS})$, IPS e.max (IE), Lava Ultimate (LU), Shofu HC (SH), Vita Enamic (VE), and Vita Suprinity (VS) and were divided into laboratory and chairside polishing. Reflection wavelength spectra, CIE D65 standard illuminant, $2^{\circ}$ standard observer, $\mathrm{SCl}$, UV included, SAV aperture, $6 \mathrm{~mm}$ diameter, were recorded at $10 \mathrm{~nm}$ sensitivity against white and black calibration tiles using a benchtop spectrophotometer. Subsequently, they were converted into CIEDE $2000 \mathrm{TP}_{00}$. After baseline measurements (T0), the specimens were divided as follows ( $n=$ 8): staining in coffee (C) and wine (W), for 60 (T1) and 120 hours (T2), and accelerated artificial aging (A). Artificial aging (ISO 4892-2 standard) was performed in two cycles of $150 \mathrm{KJ} / \mathrm{m}^{2}$, for T1 and T2, respectively. TP measurements were repeated at $\mathrm{T} 1$ and $\mathrm{T} 2$. Data of $\mathrm{TP}_{00}$ retention were submitted to analysis of variance and Fisher's PLSD multiple comparison test $(\alpha=0.05)$. Results: Fisher's PLSD critical differences among materials, time intervals and staining/aging were $0.16,0.11$ and 0.11 , respectively. SH showed the highest $T_{00}$ followed by $L U>C S>I E=V S>V E$. For all time intervals, the lowest $\mathrm{TP}_{00}$ retention was observed with C. W, and A presented similar values. Conclusions: Translucency Parameter was material, time and staining/aging-dependent material. In majority of cases, it decreased upon staining/aging.
Received: January 21, 2021

Accepted: March 1, 2021

Address for correspondence Rade Dušan Paravina, University of Texas School of Dentistry at Houston 7500 Cambridge St., Ste. 5350, Houston, Texas, 77054 Rade.Paravina@uth.tmc.edu

MeSH terms: Optical Phenomena; Coloring Agents; Age Factors; Organically Modified Ceramics; Lithium Compounds Author keywords: Optical Properties, Psychophysics, Organically Modified Ceramic, Lithium Silicate, Lithium Disilicate

\section{Introduction}

The introduction of computer aided design - computer aided manufacturing (CAD-CAM) systems in prosthodontics allowed faster production of dental restorations with higher mechanical strength compared to handmade porcelain restorations (1). In-office full digital workflow has been incorporated in daily routine, from intraoral 3D scanning to chairside CAD-CAM of restorations, because it is time saving, it reduces the quantity of patient visits to the office, and eliminates the need of a dental technician (2-3). At the same

\section{Uvod}

Uvođenje u protetiku sustava za računalno potpomognuti dizajn/računalno potpomognutu proizvodnju (CAD/ CAM) omogućilo je bržu izradu zubnih nadomjestaka veće mehaničke čvrstoće u usporedbi $s$ ručno izrađenim keramičkim nadomjestcima (1). Potpuno digitalizirani proces u ordinaciji integriran je u svakodnevnu praksu - od intraoralnoga 3D skeniranja do izrade nadomjestaka CAD/CAM tehnologijom, jer štedi vrijeme, smanjuje pacijentu broj posjeta ordinaciji i eliminira potrebu za dentalnim tehničarom $(2-3)$. 
time, new CAD-CAM materials, such as lithium silicate/disilicate ceramics, resin nanoceramics (RCN) and polymer-infiltrated ceramic-network (PICN) have been introduced and quickly have been accepted as materials of choice (4-5). These new materials are almost fully manufacturer processed, thus minimizing human related errors (6-8).

In the era of esthetic dentistry, the goal is to provide patient functional restorations whilst mimicking natural tooth appearance. Translucency, along with color, texture, size and shape, influences the appearance and optical properties of restorations.

Finishing and polishing affect the surface texture and roughness (9-10), which associated with in-mouth material aging and consumption of dark colored beverages, such as coffee, tea, red wine, and coke can provoke alterations in color and in translucency parameter (TP) of restorations (11-17). In vitro tests can be used to compare different materials under the same conditions and to predict the clinical performance (18). This study aimed to compare the TP of lithium silicate/disilicate ceramics, RCN and PICN CAD-CAM materials upon exposure to staining solutions and artificial aging (19-20). The null hypothesis was that there were no differences in TP a) among materials, b) caused by different intervals of c) immersion in staining solutions and exposure to artificial aging. In addition, comparisons between laboratory and chairside polished specimens, and correlation between $\mathrm{TP}_{00}$ and $\mathrm{TP}_{\mathrm{ab}}$ were evaluated.

\section{Material and Methods}

Six CAD-CAM materials: Cerasmart (GC, Tokyo, Japan); IPS e.max CAD (Ivoclar Vivadent, Schaan, Liechtenstein); Lava Ultimate (3M ESPE, St. Paul, MN); Shofu HC (Shofu, Kyoto, Japan); Vita Enamic (Vita Zahnfabrik, Bad Säckingen, Germany); Vita Suprinity PC (Vita Zahnfabrik) (Table 1) were tested for the translucency parameter $\left(\mathrm{TP}_{00}\right)$ at baseline and after exposure to artificial aging or staining in coffee and red wine.
Istodobno su razvijeni novi CAD/CAM materijali kao što su litijeva silikatna/disilikatna keramika, smolasta nanokeramika $(\mathrm{RCN})$ i polimerom infiltrirana keramička mreža (PICN) koji su brzo prihvaćeni kao materijali izbora $(4-5)$. Ti novi materijali gotovo su u cijelosti obrađeni tvornički pa minimaliziraju ljudske pogreške $(6-8)$.

U eri estetske stomatologije cilj je pacijentu omogućiti funkcionalne nadomjestke istodobno oponašajući prirodni izgled zuba. Translucencija, zajedno s bojom, teksturom, veličinom i oblikom, utječe na izgled i optička svojstva restauracija.

Utjecaj završne obrade i poliranja na teksturu i hrapavost površine $(9-10)$, koji su povezani sa starenjem materijala u ustima i konzumacijom obojenih pića poput kave, čaja, crnog vina i kole, može potaknuti i promjene boje i parametra translucencije (TP) restauracija $(11-17)$. Istraživanja in vitro mogu se iskoristiti za usporedbu različitih materijala u istim uvjetima i za predviđanje kliničkih rezultata (18). Cilj ovog istraživanja bio je usporediti TP litijeve silikatne/disilikatne keramike, RCN i PICN za CAD/CAM nakon izlaganja obojenim otopinama i umjetnom starenju $(19-20)$. Nulta hipoteza glasila je da nema razlika u TP-u: a) među materijalima, b) prouzročeno različitim intervalima, c) nakon djelovanja obojenih otopina i izlaganja umjetnom starenju. Uz to, uspoređeni su uzorci polirani u laboratoriju i u ordinaciji te je procijenjena korelacija između $\mathrm{TP}_{00} \mathrm{iTP}_{\mathrm{ab}}$.

\section{Materijal i metode}

Šest materijala za CAD/CAM - Cerasmart (GC, Tokio, Japan); IPS e.max CAD (Ivoclar Vivadent, Schaan, Lihtenštajn); Lava Ultimate (3M ESPE, St. Paul, MN, SAD); Shofu HC (Shofu, Kyoto, Japan); Vita Enamic (Vita Zahnfabrik, Bad Säckingen, Njemačka); Vita Suprinity PC (Vita Zahnfabrik) (tablica 1.) - testirano je s obzirom na parametar translucencije $\left(\mathrm{TP}_{00}\right)$ na početku izlaganja umjetnom starenju ili bojenju u kavi i crnom vinu te nakon toga postupka.

Table 1 Materials, acronym, type, composition, and shade.

Tablica 1. Materijali, akronim, tip, sastav i boja

\begin{tabular}{|c|c|c|}
\hline $\begin{array}{c}\text { Material, acronym, type } \bullet \\
\text { Materijal, akronim, tip }\end{array}$ & Composition • Sastav & $\begin{array}{c}\text { Shade • } \\
\text { Boja }\end{array}$ \\
\hline $\begin{array}{l}\text { Cerasmart }(\mathrm{CS}) \text {, resin nanoceramic } \bullet \\
\text { smolasta nanokeramika }\end{array}$ & $\begin{array}{l}71 \% \mathrm{SiO}_{2} \text { and barium glass nanoparticles, BisMEPP, UDMA, DMA } \\
71 \% \mathrm{SiO}_{2} \text { i nanočestice barijeva stakla, BisMEPP, UDMA, DMA }\end{array}$ & A2 LT \\
\hline $\begin{array}{l}\text { IPS Emax CAD (IE), lithium disilicate glass } \\
\text { ceramic } \bullet \text { litij-disilikatna staklokeramika }\end{array}$ & $\begin{array}{l}57-80 \% \mathrm{SiO}_{2}, 11-19 \% \mathrm{Li}_{2} \mathrm{O} \text {, other oxides } \\
57-80 \% \mathrm{SiO}_{2}, 11-19 \% \mathrm{Li}_{2} \mathrm{O} \text {, drugi oksidi }\end{array}$ & A2 LT \\
\hline $\begin{array}{l}\text { Lava Ultimate (LU), resin nanoceramic • } \\
\text { smolasta nanokeramika }\end{array}$ & $\begin{array}{l}80 \% \mathrm{SiO}_{2} \text { and } \mathrm{ZrO}_{2} \text { nanoparticle, } 20 \% \text { BisGMA, UDMA, BisEMA, TEGDMA } \\
80 \% \mathrm{SiO}_{2} \text { i } \mathrm{ZrO}_{2} \text { nanočestice, } 20 \% \text { BisGMA, UDMA, BisEMA, TEGDMA }\end{array}$ & A2 LT \\
\hline $\begin{array}{l}\text { Shofu } \mathrm{HC}(\mathrm{SH}) \text {, resin nanoceramic } \bullet \\
\text { smolasta nanokeramika }\end{array}$ & $\begin{array}{l}61 \% \mathrm{ZrSiO}_{4} \text {-based glass and } \mathrm{SiO}_{2} \text {, UDMA, TEGDMA } \\
61 \% \mathrm{ZrSiO}_{4} \text { staklo i } \mathrm{SiO}_{2}, \mathrm{UDMA}^{2}, \mathrm{TEGDMA}\end{array}$ & A2 LT \\
\hline $\begin{array}{l}\text { Vita Enamic }(\mathrm{VE}) \text {, polymer-infiltrated } \\
\text { ceramic-network } \bullet \text { polimerima infiltrirana } \\
\text { keramička mreža }\end{array}$ & $\begin{array}{l}58-63 \% \mathrm{SiO}_{2}, 20-23 \% \mathrm{Al}_{2} \mathrm{O}_{3}, 9-11 \% \mathrm{Na}_{2} \mathrm{O}, 4-6 \% \mathrm{~K}_{2} \mathrm{O}, 0.5-2 \% \mathrm{~B}_{2} \mathrm{O}_{3},<1 \% \mathrm{ZrO}_{2},<1 \% \\
\mathrm{CaO}, 14 \% \mathrm{UDMA}, \mathrm{TEGDMA} \cdot \\
58-63 \% \mathrm{SiO}_{2}, 20-23 \% \mathrm{Al}_{2} \mathrm{O}_{3}, 9-11 \% \mathrm{Na}_{2} \mathrm{O}, 4-6 \% \mathrm{~K}_{2} \mathrm{O}, 0,5-2 \% \mathrm{~B}_{2} \mathrm{O}_{3},<1 \% \mathrm{ZrO}_{2}, \\
<1 \% \mathrm{CaO}, 14 \% \text { UDMA, TEGDMA }\end{array}$ & $2 \mathrm{M} 2 \mathrm{~T}$ \\
\hline $\begin{array}{l}\text { Vita Suprinity PC (VS), zirconia reinforced } \\
\text { lithium silicate } \bullet \text { cirkonijem ojačani litij } \\
\text { silikat }\end{array}$ & $\begin{array}{l}56-64 \% \mathrm{SiO}_{2}, 15-21 \% \mathrm{Li}_{2} \mathrm{O}, 8-12 \% \mathrm{ZrO}_{2}, 1-8 \% \text { other oxides } \bullet 56-64 \% \mathrm{SiO}_{2}, 15-21 \% \\
\mathrm{Li}_{2} \mathrm{O}, 8-12 \% \mathrm{ZrO}_{2}, 1-8 \% \text { drugi oksidi }\end{array}$ & $\mathrm{A} 2 \mathrm{~T}$ \\
\hline
\end{tabular}


One millimeter thick square shaped specimens $(\mathrm{N}=$ 288), were cut from CAD-CAM blocks (shade A2 or similar) with a precision sectioning blade (IsoMet 15LC, Buehler, Lake Bluff, IL) and mounted in a precision cutter (IsoMet 1000 , Buehler). After that they were sequentially pre-polished under water cooling with \#180; 320; 400; $600 \mathrm{SiC}$ papers (Buehler) using Ecomet 6 grinder/polisher (Buehler). Specimens of each material were divided into two groups: laboratory polished and chairside polishing protocols. Polishing of all specimens was performed by the same operator (R.N.T.). Laboratory polishing was performed sequentially under water cooling with \# 800, 1200, 2400, and $4000 \mathrm{SiC}$ papers (15 seconds per grit) in an Ecomet 6 grinder/polisher at $250 \mathrm{rpm}$ under light hand pressure. Chairside polishing was performed as recommended by each manufacturer (Table 2). Light hand pressure with a low-speed handpiece (maximum 15,000 rpm) was used to polish for 30 seconds per step.
Uzorci kvadratnog oblika debljine $1 \mathrm{~mm}(\mathrm{~N}=288)$ izrezani su iz CAD/CAM blokova (nijansa A2 ili slična) oštricom za precizno rezanje (IsoMet 15LC, Buehler, Lake Bluff, IL, SAD) postavljenom u precizni rezač (IsoMet 1000, Buehler) te su polirani pod vodenim hladenjem slijedom $\mathrm{SiC}$ papira (Buehler) gruboće \#180; 320; 400; 600 u brusilici Ecomet 6 (Buehler). Uzorci svakog materijala podijeljeni su u dvije skupine - oni polirani u laboratoriju ili u ordinaciji. Poliranje svih uzoraka obavio je isti istraživač (R. N. T.). Laboratorijsko poliranje bilo je uzastopno pod vodenim hlađenjem $\mathrm{SiC}$ brusnim papirima \#800, 1200, 2400 i 4000 (15 sekunda svaki) u brusilici Ecomet 6 pri brzini od $250 \mathrm{okr} / \mathrm{min}$. pod laganim pritiskom ruke. Poliranje u ordinaciji učinjeno je prema preporukama svakog proizvođača (tablica 2.). Poliranje je izvedeno uz lagani pritisak ruke pri maloj brzini (maksimalno $15000 \mathrm{okr} / \mathrm{min}$.), 30 sekunda za svaki korak.

Uzorci su očišćeni deioniziranom vodom u ultrazvučnom čistaču (Branson Ultrasonics, Brookfield, CT, SAD) 10 mi-

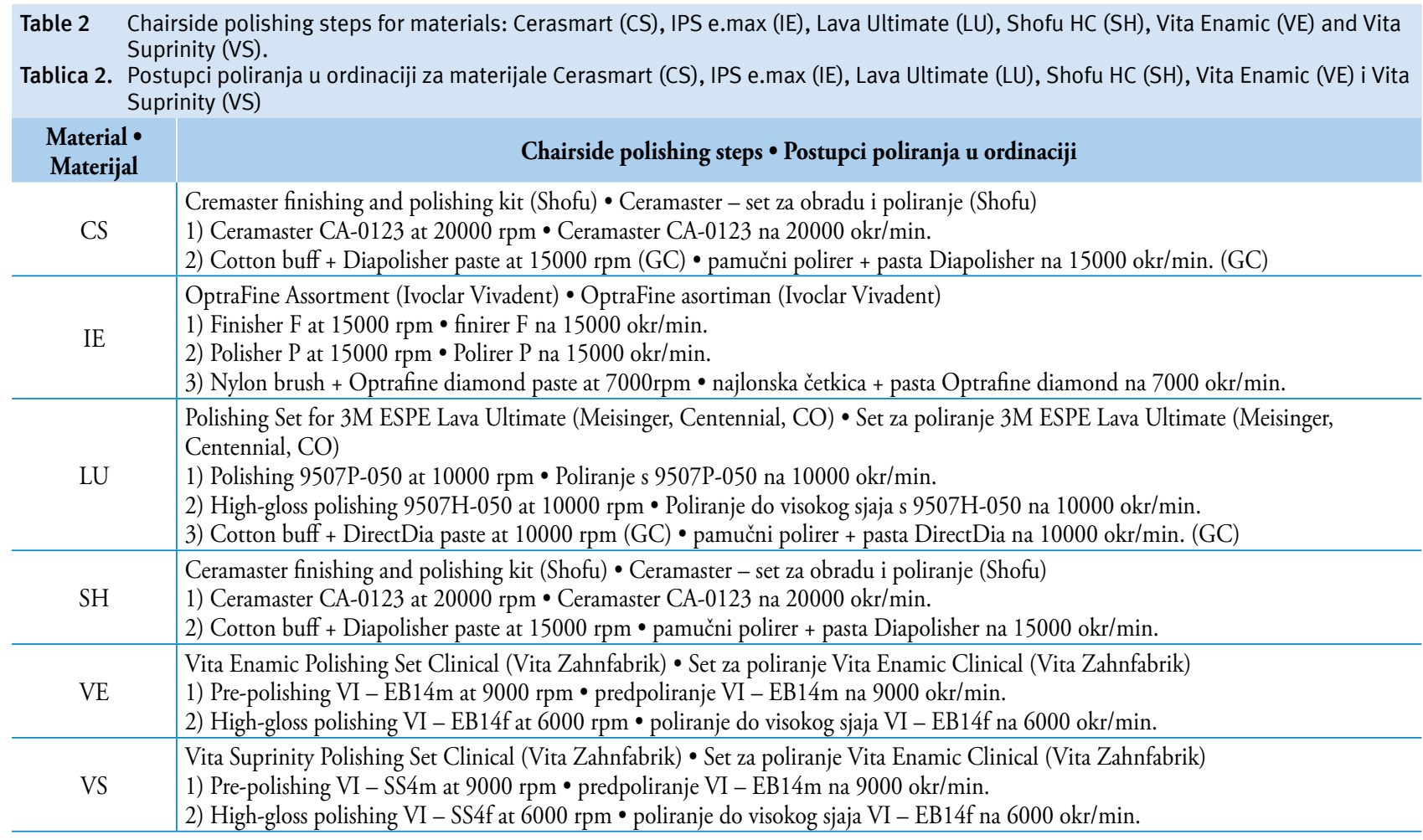

Specimens were cleaned with deionized water in an ultrasonic cleaner (Branson Ultrasonics, Brookfield, CT) for 10 minutes, and air-dried for 20 seconds for baseline $\mathrm{TP}_{00}\left(\mathrm{~T}_{0}\right)$ measurements, after which they were randomly divided into 3 subgroups $(n=8)$ : coffee or wine staining, and accelerated artificial aging. The samples were stored in staining solution in an incubator at $37^{\circ} \mathrm{C}$ in the dark for $60\left(\mathrm{~T}_{1}\right)$ and 120 hours $\left(\mathrm{T}_{2}\right)$ (solutions were changed once a day). Coffee was prepared by mixing 6 table spoons of ground coffee (Folgers Classic Roast Medium, The Folger Coffee, Orrville, $\mathrm{OH}$ ) to $600 \mathrm{ml}$ of boiling water. Cabernet Sauvignon red wine (Frontera, Concha y Toro, Santiago, Chile) was used for red wine staining. Artificial accelerated aging was performed accord- nuta i osušeni zrakom 20 sekunda prije početnog mjerenja $\mathrm{TP}_{00}\left(\mathrm{~T}_{0}\right)$, nakon čega su nasumično podijeljeni u 3 podskupine $(n=8)$ : bojenje kavom ili vinom i ubrzano umjetno starenje. Uzorci su pohranjeni u obojenoj otopini u inkubatoru na $37^{\circ} \mathrm{C}$ u mraku tijekom $60\left(\mathrm{~T}_{1}\right)$ i 120 sati $\left(\mathrm{T}_{2}\right)$ (otopine su se mijenjale jedanput na dan). Kava se pripremala miješanjem šest žlica mljevene kave (Folgers Classic Roast Medium, The Folger Coffee, Orrville, OH, SAD) u $600 \mathrm{~mL}$ kipuće vode. Za bojenje crvenim vinom korišteno je crno vino $\mathrm{Ca}$ bernet Sauvignon (Frontera, Concha y Toro, Santiago, Čile). Umjetno ubrzano starenje obavljeno je prema normi Međunarodne organizacije za standardizaciju (ISO) 4892-2, korištenjem komore za ispitivanje vremenskih uvjeta (stroj Sun- 
ing to International Organization for Standardization (ISO) 4892-2 standard, using a xenon lamp weathering and lightfastness test chamber (Suntest XXL+ machine, Ametek Atlas, Mount Prospect, IL). The artificial aging cycle consisted of light exposure (102 minutes) and water spraying (18 minutes) under artificial daylight (CIE D65 illuminant) at constant temperature $\left(37^{\circ} \mathrm{C} \pm 3{ }^{\circ} \mathrm{C}\right)$ and relative humidity $(50$ $\% \pm 10 \%$ ), with a black panel temperature of $65^{\circ} \mathrm{C}$ and irradiance control in the 300 to $400 \mathrm{~nm}$ interval of $60 \mathrm{~W} / \mathrm{m}^{2}$. The total energy delivered for artificial accelerated aging was $150 \mathrm{~kJ} / \mathrm{m}^{2}\left(\mathrm{~T}_{1}\right)$ and $300 \mathrm{~kJ} / \mathrm{m}^{2}\left(\mathrm{~T}_{2}\right)$, respectively. Measurements were repeated upon each storage period and aging cycle $\left(T_{1}\right.$ and $\left.T_{2}\right)$.

Reflection values were recorded using a bench top spectrophotometer Ci7600 (X-Rite, Grand Rapids, MI) at $10 \mathrm{~nm}$ sensitivity with the following setup: CIE D65 standard illuminant, 2 degrees 1931 standard observer, specular component included (SCI), UV component included, small area view (SAV) aperture, and 6-mm in diameter (21-22). Prior to measurements, the spectrophotometer was calibrated according to the manufacturer's instructions. Reflection spectra measurements were performed against white and black calibration tiles, thus providing comparisons within the same phase of the experiment. Reflection spectra data were converted into CIELAB and CIEDE 2000 color coordinates and the respective $\mathrm{TP}_{\mathrm{ab}}$ and $\mathrm{TP}_{00}$ values were calculated utilizing the following formulas (23):

$T P_{a b}=\left[\left(L_{W}-L_{B}\right)^{2}+\left(a_{W}-a_{B}\right)^{2}+\left(b_{W}-b_{B}\right)^{2}\right]^{\frac{1}{2}}$

|Eq. 1/,

where, $\mathrm{L}, \mathrm{a}$, and $\mathrm{b}$ denote lightness, green-red and blue-yellow coordinates, respectively, against white $\left({ }_{W}^{*}\right)$ and black $\left({ }_{B}^{*}\right)$ backgrounds.

$T P_{00}=\left[\left(\frac{L_{B}^{\prime}-L_{W}^{\prime}}{k_{L} S_{L}}\right)^{2}+\left(\frac{C_{B}^{\prime} B^{\prime} C^{\prime} W}{k_{C} S_{C}}\right)^{2}+\left(\frac{H_{B}^{\prime}-H^{\prime} W}{k_{H} S_{H}}\right)^{2}+R T\left(\frac{C_{B}^{\prime}-C^{\prime} W}{k_{C} S_{C}}\right)\left(\frac{H^{\prime} B_{B}-H^{\prime} W}{k_{H} S_{H}}\right)\right]^{\frac{1}{2}}$

/Eq. 2/

Where L', C' and H' denote lightness, chroma and hue respectively, against white $\left({ }_{W}^{*}\right)$ and black $\left({ }_{B}^{*}\right)$ backgrounds. RT (rotation function) accounts for the interaction between $\mathrm{C}^{\prime}$ and $\mathrm{H}^{\prime}$ differences in the blue region. SL, SC, and $\mathrm{SH}$ adjust the total color difference for variation in the location of the color difference specimen over ${ }_{W}^{*}$ and ${ }_{B}^{*}$ in $\mathrm{L}^{*}, \mathrm{a}^{*}$, $\mathrm{b}^{*}$ coordinates. The $\mathrm{kL}, \mathrm{kC}$, and $\mathrm{kH}$ are correction terms (24).

Data of $\mathrm{TP}_{00}$ retention were analyzed using the analysis of variance (Minitab 16, Minitab, and State College, PA). Fisher's PLSD multiple comparison test was calculated $(\alpha=0.05)$. $\mathrm{TP}_{\mathrm{ab}}$ and $\mathrm{TP}_{00}$ values were submitted to a scatterplot to generate $R^{2}$-values. TP ${ }_{00}$ differences of TP $<0.6$ and $\leq 2.6$ corresponding to the $50: 50 \%$ perceptibility threshold (PT) and 50:50\% acceptability threshold (AT) were used to interpret the results (25).

\section{Results}

Mean baseline $\mathrm{TP}_{00}$ (s.d.) values and retention (\%) upon exposure to coffee $(\mathrm{C})$, wine $(\mathrm{W})$ and aging $(\mathrm{A})$ for T0-T1, $\mathrm{T} 0-\mathrm{T} 2$ and $\mathrm{T} 1-\mathrm{T} 2$ interval comparisons are presented in the Table 3. Fisher's PLSD critical differences among materials, time intervals and staining/aging were $0.16,0.11$ and 0.11 , respectively $(\mathrm{p}<0.001$, power $=1.0)$. test XXL +, Ametek Atlas, Mount Prospect, IL, SAD). Ciklus umjetnog starenja sastojao se od izlaganja svjetlosti (102 minute) i prskanja vodom (18 minuta) pod umjetnom dnevnom svjetlošću (CIE D65 iluminant) pri konstantnoj temperaturi $\left(37^{\circ} \mathrm{C} \pm 3{ }^{\circ} \mathrm{C}\right)$ i relativnoj vlažnosti $(50 \% \pm 10 \%)$, $s$ temperaturom crne ploče od $65^{\circ} \mathrm{C}$ i kontrolom zračenja u intervalu od 300 do $400 \mathrm{~nm}$ od $60 \mathrm{~W} / \mathrm{m}^{2}$. Ukupna energija isporučena za umjetno ubrzano starenje iznosila je $150 \mathrm{~kJ} / \mathrm{m}^{2}$ $\left(\mathrm{T}_{1}\right)$, odnosno $300 \mathrm{~kJ} / \mathrm{m}^{2}\left(\mathrm{~T}_{2}\right)$. Nakon svakog razdoblja skladištenja i ciklusa starenja $\left(\mathrm{T}_{1}^{2} \mathrm{i} \mathrm{T}_{2}\right)$ mjerenja su ponovljena.

Vrijednosti refleksije zabilježene su s pomoću spektrofotometra Ci7600 (X-Rite, Grand Rapids, MI, SAD) pri osjetljivosti od $10 \mathrm{~nm}$, uz sljedeće postavke: CIE D65 standardno osvjetljenje, standardni promatrač 1931 na 2 stupnja, uključena zrcalna komponenta (SCI), uključena UV komponenta, mali otvor (SAV) i promjer $6 \mathrm{~mm}(21-22)$. Prije mjerenja spektrofotometar je kalibriran prema uputama proizvođača. Mjerenja spektralne refleksije učinjena su na bijelim i crnim kalibracijskim pločicama i dala su usporedne vrijednosti u istoj fazi eksperimenta. Podatci o refleksijskim spektrima pretvoreni su u koordinate boja CIELAB i CIEDE 2000, a odgovarajuće vrijednosti $\mathrm{TP}_{a b}$ i $\mathrm{TP}_{00}$ izračunane su s pomoću sljedećih jednadžbi (23):

$T P_{a b}=\left[\left(L_{W}-L_{B}\right)^{2}+\left(a_{W}-a_{B}\right)^{2}+\left(b_{W}-b_{B}\right)^{2}\right]^{\frac{1}{2}}$

/Jdn. $1 /$

gdje L, a i b označavaju svjetlost, zeleno-crvenu i plavo-žutu koordinatu na bijeloj $\left({ }_{\mathrm{W}}^{*}\right)$ i $\operatorname{crnoj}\left({ }_{\mathrm{B}}^{*}\right)$ pozadini.

$T P_{00}=\left[\left(\frac{L_{B}^{\prime}-L_{W}^{\prime}}{k_{L} S_{L}}\right)^{2}+\left(\frac{C_{B}^{\prime}-C_{W}^{\prime} W}{k_{C} S_{C}}\right)^{2}+\left(\frac{H^{\prime} B^{-} H_{W}^{\prime}}{k_{H} S_{H}}\right)^{2}+R T\left(\frac{C_{B}^{\prime}-C_{W}^{\prime} W}{k_{C} S_{C}}\right)\left(\frac{H^{\prime} B_{B}-H^{\prime} W}{k_{H} S_{H}}\right)\right]^{\frac{1}{2}}$

IJdn. 2/

gdje L', C' i H 'označuju svjetlinu, obojenost i nijansu, u odnosu prema bijeloj $\left({ }_{\mathrm{W}}^{*}\right)$ i crnoj $\left({ }_{\mathrm{B}}^{*}\right)$ pozadini. RT (funkcija rotacije) objašnjava interakciju između razlika C 'i H' u plavoj regiji. SL, SC i SH prilagođavaju ukupnu razliku u boji za varijaciju mjesta razlike boje u odnosu prema ${ }_{W}^{*} \mathrm{i}^{*}{ }_{\mathrm{B}} \mathrm{u}$ koordinatama $L^{*}, a^{*}, b^{*}$. Pojmovi korekcije su kL, kC i kH (24).

Podatci o zadržavanju $\mathrm{TP}_{00}$ analizirani su analizom varijance (Minitab 16, Minitab, State College, PA, SAD). Izračun je napravljen Fisherovim testom za višestruke usporedbe $(\alpha=0,05)$. Vrijednosti $\mathrm{TP}_{\mathrm{ab}} \mathrm{iTP}_{00}$ stavljene su u raspršeni dijagram kako bi se generirale $\mathrm{R}^{2}$-vrijednosti. $\mathrm{Za}$ interpretaciju rezultata upotrijebljene su $\mathrm{TP}_{00}$ razlike za $\mathrm{TP}<0,6 \mathrm{i} \leq 2,6$ koje odgovaraju pragu percepcije od $50: 50 \%$ (PT) i pragu prihvatljivosti od $50: 50 \%$ (AT) (25).

\section{Rezultati}

Prosječne početne vrijednosti $\mathrm{TP}_{00}$ (s. d.) i zadržavanje (\%) nakon izloženosti kavi (C), vinu (W) i umjetnom starenju (A) za usporedbe T0 -T1, T0 - T2 i T1 T2 prikazane su u tablici 3. Kritične razlike Fisherova PLSD-testa između materijala, vremenskih intervala i bojenja/starenja iznosile su $0,16,0,11$ i $0,11(\mathrm{p}<0,001$, snaga $=1,0)$. 
Table 3 Baseline TP ${ }_{00}$ (s.d.) values and retention percentage upon exposure to coffee (C), wine $(\mathrm{W})$ and aging $(\mathrm{A})$ for T0-T1, T0-T2 and T1-T2 interval comparisons

Tablica 3. Početni $\mathrm{TP}_{00}$ (s. d.) vrijednosti i retencija (\%) nakon izlaganja kavi (C), vinu (W) i starenju (A) za usporedbe intervala $\mathrm{TO}-\mathrm{T} 1, \mathrm{TO}-\mathrm{T} 2 \mathrm{i}$ $\underline{\mathrm{T}} 1-\underline{\mathrm{T} 2}$

\begin{tabular}{c|c|c|c} 
Material $\bullet$ Materijal & C & W & A \\
CS & $12(0.4) / 100.5 / 96.9 / 96.4$ & $12.4(0.4) / 98.9 / 98.7 / 99.8$ & $12.3(0.3) / 99.3 / 97.6 / 98.3$ \\
\hline IE & $11.6(0.6) / 97.9 / 98.5 / 100.6$ & $11.5(0.2) / 101.0 / 98.7 / 97.7$ & $11.9(0.8) / 97.6 / 97.9 / 100.3$ \\
\hline LU & $13.2(0.2) / 93.5 / 90.4 / \underline{96.7}$ & $13.3(0.6) / 95.3 / 93.8 / \underline{98.4}$ & $13(0.2) / 98.7 / 98.1 / 99.4$ \\
\hline SH & $13.5(0.2) / 94.2 / 91.1 / \underline{96.7}$ & $13.6(0.5) / 95.8 / 94.7 / 98.9$ & $13.3(0.3) / 97.5 / 97.0 / 99.5$ \\
\hline VE & $8.7(0.2) / 93.8 / 89.6 / 95.5$ & $8.5(0.1) / 93.6 / 91.1 / 97.4$ & $9.2(0.1) / 99.9 / 99.3 / 99.4$ \\
\hline VS & $11.4(0.6) / 96.6 / 95.2 / \underline{98.6}$ & $11.5(0.7) / 96.8 / 97.7 / 100.0$ & $11.8(1.3) / 96.6 / 97.5 / 100.9$ \\
\hline
\end{tabular}

SH showed the highest $\mathrm{TP}_{00}$ followed by $\mathrm{LU}>\mathrm{CS}>\mathrm{IE}=$ VS > VE. For all time intervals (T0-T1, T0-T2 and T1-T2), the lowest $\mathrm{TP}_{00}$ retention was observed with $\mathrm{C}$. W and A presented similar values.

Figure 1 presents the comparison between corresponding $\mathrm{TP}_{\mathrm{ab}}$ and $\mathrm{TP}_{00}$ values, the coefficient of determination $\left(R^{2}\right)$, and an equation to calculate $\mathrm{TP}_{00}$ values based on known $\mathrm{TP}_{\mathrm{ab}}$ values.

The results of $t$ test for $\mathrm{TP}_{00}$ from laboratory and chairside polished specimens showed no significant difference between them $(p$-value $=0.67)$. A comparison between the corresponding $\mathrm{TP}_{00}$ and $\mathrm{TP}_{\mathrm{ab}}$ values, the coefficient of determination $\left(R^{2}\right)$, and an equation to calculate $\mathrm{TP}_{00}$ values based on known $\mathrm{TP}_{\mathrm{ab}}$ values are presented in Figure 1. The opposite equation, to calculate $\mathrm{TP}_{\mathrm{ab}}$ values based on known $\mathrm{TP}_{00}$, was as follows: $\mathrm{TP}_{\mathrm{ab}}=1.1 \mathrm{TP}_{00}^{\mathrm{ab}}+2.8\left(R^{2}=0.97\right)$.
$\mathrm{SH}$ je imao najviši $\mathrm{TP}_{00}$ praćen $s \mathrm{LU}>\mathrm{CS}>\mathrm{IE}=\mathrm{VS}>$ VE. Za sve intervale (T0 - T1, T0 - T2 i T1 - T2) zabilježeno je najmanje zadržavanje $\mathrm{TP}_{00}$ kod $\mathrm{C}$-a. Slične vrijednosti imali su W i A.

Na slici 1. je usporedba između odgovarajućih vrijednosti $\mathrm{TP}_{\mathrm{ab}}$ i $\mathrm{TP}_{00}$, koeficijenta determinacije $\left(\mathrm{R}^{2}\right) \mathrm{i}$ jednadžbe za izračunavanje vrijednosti $\mathrm{TP}_{00}$ na temelju poznatih vrijednosti TP

Rezultati t-testa za $\mathrm{TP}_{00}$ uzoraka poliranih u laboratoriju i ordinaciji nisu pokazali značajnu razliku među njima (p-vrijednost $=0,67)$. Usporedbe između odgovarajućih vrijednosti $\mathrm{TP}_{00} \mathrm{i} \mathrm{TP}_{\mathrm{ab}}$, koeficijenta determinacije $\left(\mathrm{R}^{2}\right) \mathrm{i}$ jednadžbe za izračunavanje vrijednosti $\mathrm{TP}_{00}$ na temelju poznatih vrijednosti TP prikazane su na slici 1. Suprotna jednadžba za izračunavanje vrijednosti $\mathrm{TP}_{\mathrm{ab}}$ na temelju poznatoga $\mathrm{TP}_{00}$ glasila je: $\mathrm{TP}_{\mathrm{ab}}=1,1 \mathrm{TP}_{00}+2,8\left(\mathrm{R}^{2}=0,97\right)$.

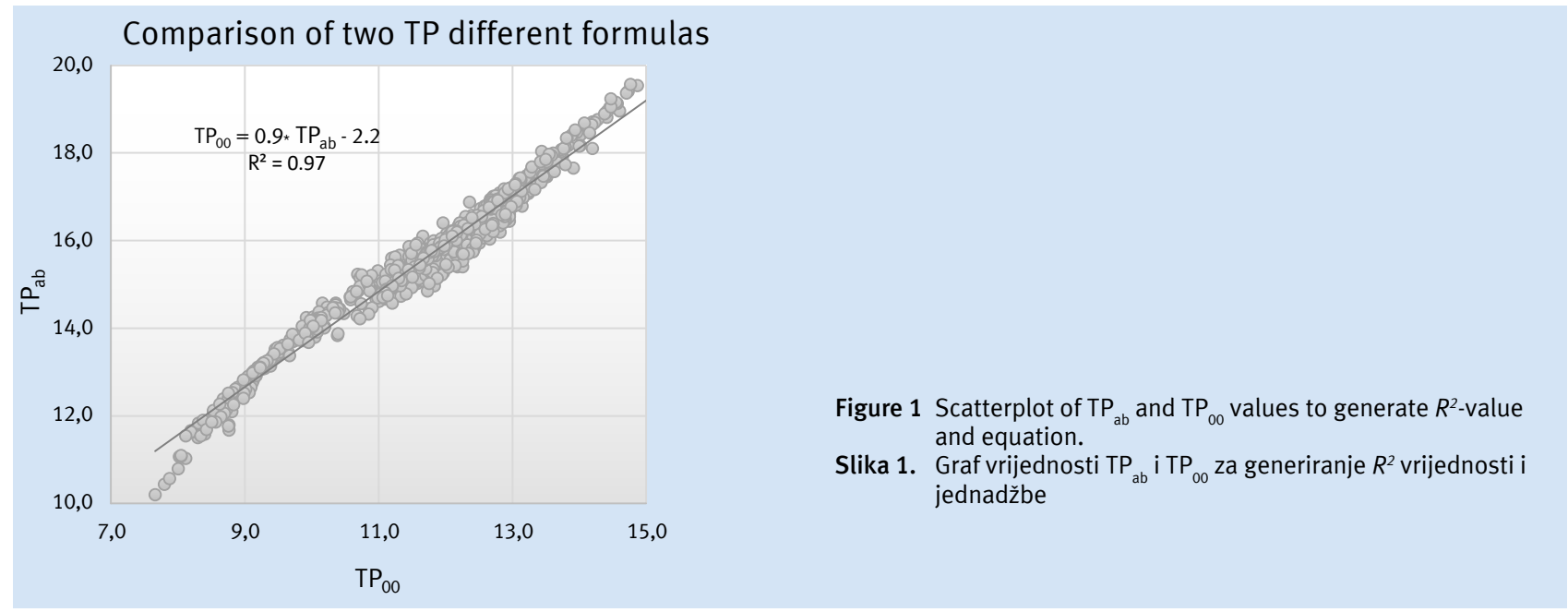

\section{Discussion}

The instability of color and translucency can affect the esthetics of a restoration, and depending on the severity may lead to the need of its replacement (26). Restorations involving high chroma dental remnant and endodontic posts are very challenging regarding translucency of restorative material. In such cases, high translucent materials are not acceptable because they cannot mask the background properly. The higher the TP value, the more translucent the material becomes. Therefore, lower TP stands for decreased translucency of the same material after staining and aging, or lower trans-

\section{Rasprava}

Nestabilnost boje i translucencije može utjecati na estetiku nadomjestka, a ovisno o težini može zahtijevati njegovu zamjenu (26). Nadomjestci na visokokromatskim ostatcima zuba i metalnim nadogradnjama vrlo su izazovni s obzirom na translucenciju restaurativnog materijala. $U$ takvim slučajevima visokotranslucentni materijali nisu prihvatljivi jer ne mogu pravilno prikriti pozadinu. Śto je viši TP, to je materijal prozirniji, stoga niži TP znači smanjenu prozirnost istog materijala nakon bojenja i starenja ili manju prozirnost između različitih materijala. 
lucency between different materials.

It was observed that Shofu HC presented the highest $\mathrm{TP}_{00}$, followed by Lava Ultimate and Cerasmart, respectively. IPS Emax and Vita Suprinity showed intermediate values, while Vita Enamic presented the lowest $\mathrm{TP}_{00}$ values. Higher TP values were reported for RNC materials, such as Shofu HC, Lava Ultimate and Cerasmart, compared to other materials (27-29). Conversely, similar TP values between RNC and PICN have been reported (11). It can be hypothesized that similar refractive index between the inorganic filler and the organic phase in RNC contributes to this result. The grain size, chemical composition, crystalline structure and internal flaws have been related to TP change of dental ceramics $(6,30)$. Zircon dioxide reinforced glass ceramics presents 4 to 8 times smaller grain size compared to lithium disilicate ceramics (7).

Coffee provoked the greatest TP changes, followed by red wine and artificial aging, which showed to be alike. It was reported that yellow stain molecules with low polarity present in coffee are attracted by the polymer network leading to greater color changes (31) and that coffee and wine affect translucency and color significantly $(12,32)$. The $\mathrm{TP}_{00}$ mean values and $\mathrm{TP}_{00}$ retention decreased from $\mathrm{T} 0-\mathrm{T} 1$ to $\mathrm{T} 0-\mathrm{T} 2$. Therefore, the null hypothesis that there were no differences in TP among materials, caused by different intervals of immersion in staining solutions and exposure to artificial aging was rejected.

The $t$-test comparison results showed no difference between $\mathrm{TP}_{00}$ of laboratory and chairside polished specimens. This is in agreement with previous studies which showed similar TP values with different finishing and polishing protocols for the same material (27-28). Since digital workflow from $3 \mathrm{D}$ scanning to chairside polishing has been implemented in office routine, we only presented the data on chairside polished specimens. Additionally, since a high correlation was observed between the values obtained by $\mathrm{TP}_{00}$ and $\mathrm{TP}_{\mathrm{ab}}$ formulas, conversion equations between them were presented in order to allow the comparison of the results of studies using only 1 of these formulas.

The clinical visual evaluation of differences in translucency is complex and difficult (33). The implementation of visual thresholds facilitated the evaluation of color and translucency, contributing to the follow-up of restorations and quality control of materials (34). Although the statistical analysis had shown significant differences among staining solutions and aging, the baseline $\mathrm{DTP}_{00}$ among them were graded as excellent match (below 50:50\% perceptibility threshold, 0.6), except the comparison between red wine and artificial aging for Vita Enamic $\left(\mathrm{DTP}_{00}=0.7\right)$ which was graded as an acceptable match, still below the 50:50\% TP acceptability threshold, 2.6 (25). The DTP 00 graded as excellent match was observed for comparisons between coffee and red wine ( 0.0 to $0.5)$ for all time intervals. For the comparisons between red wine and artificial aging, excellent match was observed for all DTP ${ }_{00}$ except for VE (0.7) at T0-T2 interval, which was graded as acceptable match. For the comparisons between coffee and artificial aging, excellent match was noticed, except for LU (0.7 and 1.0) at T0-T1 and T0-T2, respective-
Uočeno je da je Shofu HC imao najviši $\mathrm{TP}_{00}$, zatim su srednje vrijednosti imali Lava Ultimate i Cerasmart. IPS E.max i Vita Suprinity, a Vita Enamic imao je najniže vrijednosti $\mathrm{TP}_{00}$. Zabilježene su veće vrijednosti TP-a za RNC materijale, kao što su Shofu HC, Lava Ultimate i Cerasmart, u usporedbi s ostalim materijalima $(27-29)$. Suprotno tomu zabilježene su slične vrijednosti TP-a između RNC-a i PICNa (11). Može se pretpostaviti da sličan indeks loma između anorganskoga punila i organske faze u RNC-u pridonosi tom rezultatu. Veličina zrna, kemijski sastav, kristalna struktura i unutarnji nedostatci povezani su s promjenom TP-a dentalne keramike $(6,30)$. Staklokeramika ojačana cirkonijevim dioksidom ima od 4 do 8 puta manju veličinu zrna u odnosu prema litijevoj disilikatnoj keramici (7).

Kava je prouzročila najveće promjene TP-a, a sličnima su se pokazali crveno vino i umjetno starenje. Navodi se da polimerna mreža privlači molekule žutoga pigmenta s niskim polaritetom u kavi, što rezultira većim promjenama boje (31) te da kava i vino značajno utječu na translucenciju i boju (12, 32). Prosječne vrijednosti $\mathrm{TP}_{00}$ i zadržavanja $\mathrm{TP}_{00}$ smanjile su se s T0 - T1 na T0 - T2. Stoga je odbačena naša hipoteza da među materijalima nije bilo razlika u TP-u prouzročenih različitim intervalima pri uranjanju u obojene otopine i izloženošću umjetnom starenju.

Rezultati usporedbe t-testom nisu pokazali razliku između $\mathrm{TP}_{00}$ za uzorke polirane u laboratoriju i u ordinaciji. To se slaže s rezultatima dosadašnjih istraživanja u kojima su autori dobili slične vrijednosti TP-a $s$ različitim protokolima obrade i poliranja za isti materijal (27 - 28), a kako je digitalizirani tijek rada, od 3D skeniranja do poliranja, implementiran u ordinacijsku svakodnevicu prikazali smo podatke za uzorke polirane u ordinaciji. Budući da je uočena visoka korelacija između vrijednosti dobivenih jednadžbama $\mathrm{TP}_{00} \mathrm{i} \mathrm{TP}_{\mathrm{ab}}$, prikazane su jednadžbe pretvorbe između njih kako bi se mogli usporediti rezultati istraživanja korištenjem samo jedne od tih jednadžbi.

Klinička vizualna procjena razlika u translucenciji složena je i teška (33). Primjena vizualnih pragova olakšala je procjenu boje i translucencije te je pridonijela jednostavnijem praćenju restauracija i kontroli kvalitete materijala (34). Iako je statistička analiza pokazala značajne razlike između obojenih otopina i starenja, početna vrijednost $\mathrm{DTP}_{00}$ među njima ocijenjena je kao izvrsno podudaranje (prag percepcije ispod $50: 50 \%, 0,6$ ), osim usporedbe između crnoga vina i umjetnog starenja za Vita Enamic $\left(\mathrm{DTP}_{00}=0,7\right)$ koje je ocijenjeno kao prihvatljivo podudaranje, još uvijek ispod praga prihvatljivosti TP-a od 50 : 50 \%, 2,6 (25). DTP ${ }_{00}$ ocijenjen kao izvrsno podudaranje zabilježen je za usporedbe između kave i crnoga vina $(0,0$ do 0,5$)$ za sve intervale. Za usporedbu između crnoga vina i umjetnog starenja uočeno je izvrsno podudaranje za sve $\mathrm{DTP}_{00}$, osim za VE $(0,7)$ u intervalu T0 - T2, što je ocijenjeno kao prihvatljivo podudaranje. Za usporedbe između kave i umjetnog starenja zabilježeno je izvrsno podudaranje, osim za LU $(0,7$ i 1,0$)$ kod T0 - T1, odnosno T0 - T2 i SH $(0,8)$ i VE $(0,8)$ u intervalu T0 - T2. Usporedbe među vremenskim intervalima pokazale su prihvatljivo podudaranje za LU $(0,8)$, SH $(0,7)$ i VE $(0,8)$ obojene crvenim vinom za interval T0 - T2, za LU $(0,9$ i 1,3$)$ i SH $(0,8$ i 
ly, for SH (0.8) and VE (0.8) at T0-T2 interval. The comparisons between time intervals showed acceptable match for LU (0.8), SH (0.7) and VE (0.8) stained with red wine for T0-T2 interval, for $\mathrm{LU}(0.9$ and 1.3$)$ and $\mathrm{SH}(0.8$ and 1.2) stained with coffee for T0-T1 and T0-T2 intervals, respectively. The $\mathrm{DTP}_{00}$ graded as acceptable match was also recorded for VE (0.9) for T0-T2 interval. Excellent match was observed for all other experimental conditions.

The continued exposure to staining and aging imposed in this in vitro study was harsher than in mouth in vivo challenge. Moreover, in the present study, both surfaces of specimens were exposed to staining and aging, which might have increased the DTP. However, in vitro comparisons among materials under the same test conditions can provide results to guide material selection. Intraorally, staining and aging of restorations can be further associated with oral hygiene, smoking and tooth whitening. Further research combining previously mentioned factors and repolishing of material surface should be considered, despite the fact that complex combinations mimicking in vivo scenario hinder information of isolated variables.

\section{Conclusions}

Within the limitations of this study, it was concluded that: Translucency Parameter (TP) was material, time and staining/aging-dependent material; Shofu HC exhibited the highest TP, followed by Lava Ultimate and Cerasmart, respectively. Lower values were recorded for IPS Emax, Vita Suprinity and Vita Enamic; Coffee caused the greatest decrease in TP, followed by wine and aging, which showed similar effects. Staining and artificial aging-dependent changes in TP were increased with the increase of exposure; No difference in TP was found between laboratory and chairside polished specimens. $\mathrm{TP}_{00}$ and $\mathrm{TP}_{\mathrm{ab}}$ values were highly correlated.

\section{Conflict of interests}

The authors report no conflict of interests.

\section{Acknowledgment}

Authors thank to Dr. John M. Powers for the statistical analysis.

Author's contribution: R.N.T. - Conceptualization; Data curation; Formal analysis; Investigation; Methodology; Project administration; Resources; Software; Supervision; Validation; Visualization; Roles/ Writing - original draft, review \& editing; A.T. - Conceptualization; Data curation; Formal analysis; Investigation; Methodology; Resources; Roles/Writing - original draft, review \& editing; D.S. -Conceptualization; Data curation; Formal analysis; Investigation; Methodology; Visualization; Roles/Writing - original draft, review \& editing; D.N.K - Conceptualization; Data curation; Formal analysis; Investigation; Methodology; Resources; Visualization; Roles/Writing - original draft, review \& editing; I.S. - Conceptualization; Data curation; Formal analysis; Investigation; Methodology; Resources; Software; Visualization; Roles/Writing - original draft, review \& editing; R.D.P. - Conceptualization; Data curation; Formal analysis; Investigation; Methodology; Project administration; Resources; Software; Supervision; Validation; Visualization; Roles/Writing - original draft, review \& editing.
1,2) obojene kavom za intervale T0 - T1, odnosno T0 - T2. $\mathrm{DTP}_{00}$ ocijenjeno kao prihvatljivo podudaranje zabilježeno je i za VE $(0,9)$ za interval T0 - T2. Izvrsno podudaranje uočeno je za sve ostale eksperimentalne uvjete.

Kontinuirano izlaganje bojenju i starenju u ovom istraživanju in vitro bilo je ekstremnije nego što su uvjeti in vivo u ustima. Štoviše, u ovom su istraživanju obje površine uzoraka bile izložene bojenju i starenju, što bi moglo povećati DTP. No usporedbe materijala in vitro u istim uvjetima istraživanja mogu dati rezultate koji će pomoći u odabiru materijala. Intraoralno bojenje i starenje nadomjestaka mogu se, među ostalim, dodatno povezati s oralnom higijenom, pušenjem i izbjeljivanjem zuba. Treba razmotriti buduća istraživanja koja bi kombinirala spomenute čimbenike i ponovno poliranje površine materijala, unatoč činjenici da složene kombinacije koje oponašaju uvjete in vivo ometaju informacije o izoliranim varijablama.

\section{Zaključci}

Prema ograničenim nalazima u ovom istraživanju doneseni su sljedeći zaključci: parametar translucencije (TP) ovisio je o materijalu, vremenu i bojenju/starenju; Shofu HC imao je najviši TP, a slijedili su ga Lava Ultimate i Cerasmart. Niže vrijednosti zabilježene su za IPS E.max, Vita Suprinity i Vita Enamic; kava je prouzročila najveći pad TP-a, praćena vinom i starenjem koji su imali sličan učinak. Promjene TP-a ovisne o bojenju i umjetnom starenju povećavale su se s povećanjem izloženosti; nije ustanovljena razlika u TP-u između uzoraka poliranih u laboratoriju i u ordinaciji. Vrijednosti $\mathrm{TP}_{00} \mathrm{iTP}_{\mathrm{ab}}$ bile su u visokoj korelaciji.

\section{Sukob interesa}

Autori nisu bili u sukobu interesa.

\section{Zahvale}

Autori zahvaljuju dr. Johnu M. Powersu na statističkoj analizi.

Doprinos autora: R. N. T. - konceptualizacija, uređivanje podata$\mathrm{ka}$, formalna analiza, istraga, metodologija, administracija projekta, resursi, softver, nadzor, provjera valjanosti, vizualizacija, pisanje - izvorni nacrt, pregled i uređivanje; A. T. - konceptualizacija, uređivanje podataka, formalna analiza, istraga, metodologija, resursi, pisanje - izvorni nacrt, pregled i uređivanje; D. S. - konceptualizacija, uređivanje podataka, formalna analiza, istraga, metodologija, vizualizacija, pisanje - izvorni nacrt, pregled i uređivanje; D. N. K. - konceptualizacija, uredivanje podataka, formalna analiza, istraga, metodologija, resursi, vizualizacija, pisanje - izvorni nacrt, pregled i uređivanje; I. S. - konceptualizacija, uređivanje podataka, formalna analiza, istraga, metodologija, resursi, softver, vizualizacija, pisanje - izvorni nacrt, pregled i uređivanje; R. D. P. - konceptualizacija, uređivanje podataka, formalna analiza, istraga, metodologija, administracija projekta, resursi, softver, nadzor, provjera valjanosti, vizualizacija, pisanje - izvorni nacrt, pregled i uređivanje. 


\section{Sažetak}

Svrha rada: Procijeniti utjecaj različitih intervala izloženosti otopinama za bojenje i umjetnom starenju na parameter translucencije (TP ${ }_{00}$ CAD/CAM materijala. Materijal i metode: Uzorci kvadratnog oblika debljine $1 \mathrm{~mm}(\mathrm{~N}=288)$ izrezani su iz blokova Cerasmart (CS), IPS e.max (IE), Lava Ultimate (LU), Shofu HC (SH), Vita Enamic (VE) i Vita Suprinity (VS) te su razvrstani u skupine u kojima je provedeno poliranje ili u laboratoriju ili u ordinaciji. Mjereni su referentnim spektrofotometrom spektri valne duljine refleksije (standardno osvjetljenje CIE D65, standardni promatrač od $2^{\circ}, \mathrm{SCl}$, uključen UV, otvor SAV, promjer $6 \mathrm{~mm}$ ) pri osjetljivosti od $10 \mathrm{~nm}$ na bijelim i crnim kalibracijskim pločicama i pretvoreni u CIEDE $2000 \mathrm{TP}_{00}$. Nakon početnih mjerenja (T0) uzorci su podijeljeni na sljedeći način ( $n=8)$ : bojenje u kavi (C) i vinu (W) 60 (T1) i 120 sati (T2) te ubrzano umjetno starenje (A) . Umjetno starenje (ISO 4892-2 standard) obavljeno je u dvama ciklusima od $150 \mathrm{KJ} / \mathrm{m} 2$, za T1, odnosno T2. Mjerenja TP-a ponovljena su nakon T1 i T2. Podatci o TP podvrgnuti su analizi varijance Fisherovim PLSD- testom višestruke usporedbe $(\alpha=0,05)$. Rezultati: Kritične razlike Fisherova PLSD-testa između materijala, vremenskih intervala i bojenja/starenja bile su $0,16,0,11$, odnosno 0,11 . SH je imao najviši $T P_{00}$, a zatim slijede $L U>C S>I E=V S>V E$. Za sve intervale zabilježeno je najmanje zadržavanje TP ${ }_{00}$ kod C-a. Slične vrijednosti imali su W i A. Zaključci: Parametar translucencije ovisio je o materijalu, vremenu i bojenju/starenju. U većini slučajeva smanjio se nakon bojenja/starenja.
Zaprimljen: 21. siječnja 2021 Prihvaćen: 1. ožujka 2021.

Adresa za dopisivanje Rade Dušan Paravina, University of Texas School of Dentistry at Houston 7500 Cambridge St., Ste. 5350, Houston, Texas, 77054 Rade.Paravina@uth.tmc.edu

MeSH pojmovi: optički fenomeni; bojila; vrijeme djelovanja; organski preinačene keramike; smjese litija Ključne riječi: optička svojstva, psihofizika, organski modificirana keramika, litijev silikat, litijev disilikat

\section{References}

1. Rekow ED. Dental CAD/CAM systems: a 20-year success story. J Am Dent Assoc. 2006 Sep;137 Suppl:5S-6S.

2. Joda T, Zarone F, Ferrari M. The complete digital workflow in fixed prosthodontics: a systematic review. BMC Oral Health. 2017 Sep 19;17(1):124.

3. Tordiglione L, De Franco M, Bosetti G. The Prosthetic Workflow in the Digital Era. Int J Dent. 2016;2016:9823025.

4. Della Bona A, Corazza PH, Zhang Y. Characterization of a polymer-infiltrated ceramic-network material. Dent Mater. 2014 May;30(5):564-9.

5. Coldea A, Swain MV, Thiel N. Mechanical properties of polymer-infiltrated-ceramic-network materials. Dent Mater. 2013 Apr;29(4):419-26.

6. Vichi A, Carrabba M, Paravina R, Ferrari M. Translucency of ceramic materials for CEREC CAD/CAM system. J Esthet Restor Dent. 2014;26(4):224-31.

7. Sen N, Us YO. Mechanical and optical properties of monolithic CAD-CAM restorative materials. J Prosthet Dent. 2018 Apr;119(4):593-599.

8. Wang F, Takahashi H, Iwasaki N. Translucency of dental ceramics with different thicknesses. I Prosthet Dent. 2013 Jul;110(1):14-20.

9. Sagsoz O, Demirci T, Demirci G, Sagsoz NP, Yildiz M. The effects of different polishing techniques on the staining resistance of CAD/ CAM resin-ceramics. J Adv Prosthodont. 2016 Dec;8(6):417-422.

10. Yilmaz C, Korkmaz T, Demirköprülü H, Ergün G, Ozkan Y. Color stability of glazed and polished dental porcelains. J Prosthodont. 2008 Jan;17(1):20-4.

11. Barutçugil Ç, Bilgili D, Barutcigil K, Dündar A, Büyükkaplan UŞ, Yilmaz B. Discoloration and translucency changes of CAD-CAM materials after exposure to beverages. J Prosthet Dent. 2019 Sep;122(3):325-331.

12. Quek SHQ, Yap AUJ, Rosa V, Tan KBC, Teoh KH. Effect of staining beverages on color and translucency of CAD/CAM composites. Esthet Restor Dent. 2018;30(2):E9-E17.

13. Stawarczyk B, Liebermann A, Eichberger M, Güth JF. Evaluation of mechanical and optical behavior of current esthetic dental restorative CAD/CAM composites. J Mech Behav Biomed Mater. 2015 Mar;55:1-11.

14. Gasparik C, Culic B, Varvara MA, Grecu A, Burde A, Dudea D. Effect of accelerated staining and bleaching on chairside CAD/CAM materials with high and low translucency. Dent Mater J. 2019 Dec 1;38(6):987-993.

15. Lawson NC, Burgess JO. Gloss and Stain Resistance of Ceram ic-Polymer CAD/CAM Restorative Blocks. J Esthet Restor Dent. 2016;28(Suppl 1):S40-S45.

16. Arif $R$, Yilmaz B, Johnston WM. In vitro color stainability and relative translucency of CAD-CAM restorative materials used for laminate veneers and complete crowns. J Prosthet Dent. 2019 Aug;122(2):160-166.

17. Stamenković D, Tango RN, Todorović A, Karasan D, Sailer I, Paravina RD. Staining and aging-dependent changes in color of CAD-CAM materials. J Prosthet Dent. 2020 Oct 8;S0022 3913(20)30469-8.

18. de Oliveira DC, Ayres AP, Rocha MG, Giannini M, Puppin Rontan RM, Ferracane JL, et al. Effect of Different In Vitro Aging Methods on Color Stability of a Dental Resin-Based Composite Using CIELAB and CIEDE2000 Color-Difference Formulas. I Esthet Restor Dent. 2015;27(5):322-30.
19. Egilmez F, Ergun G, Cekic-Nagas I, Vallittu PK, Lassila LVJ. Comparative color and surface parameters of current esthetic restorative CAD/CAM materials. J Adv Prosthodont. 2018 Feb;10(1):32-42.

20. Carrabba M, Vichi A, Vultaggio G, Pallari S, Paravina R, Ferrari M. Effect of Finishing and Polishing on the Surface Roughness and Gloss of Feldspathic Ceramic for Chairside CAD/CAM Systems. Oper Dent. Mar/Apr 2017;42(2):175-184.

21. Paravina RD, Pereira Sanchez NA, Tango RN. Harmonization of color measurements for dental application. Color Res Appl. 2020; 1-7.

22. Paravina RD, Aleksić A, Tango RN, García-Beltrán A, Johnston WM, Ghinea RI. Harmonization of color measurements in dentistry. Measurement. 2021;169:108504.

23. CIE Technical report: Colorimetry. CIE Pub No 15.4. Vienna, Austria: CIE Central Bureau; 2018.

24. Salas M, Lucena C, Herrera LJ, Yebra A, Della Bona A, Pérez MM. Translucency thresholds for dental materials. Dent Mater. 2018 Aug;34(8):1168-1174.

25. Paravina RD, Ghinea R, Herrera LJ, Bona AD, Igiel C, Linninger $M$, et al. Color difference thresholds in dentistry. J Esthet Restor Dent. Mar-Apr 2015;27 Suppl 1:S1-9.

26. de Azevedo Cubas GB, Camacho GB, Demarco FF, Pereira-Cenci $T$. The Effect of Luting Agents and Ceramic Thickness on the Color Variation of Different Ceramics against a Chromatic Background. Eur J Dent. 2011 Jul;5(3):245-52

27. Kurt M, Turhan Bal B. Effects of accelerated artificial aging on the translucency and color stability of monolithic ceramics with different surface treatments. J Prosthet Dent. 2019 Apr;121(4):712. e1-712.e8.

28. Vichi A, Sedda M, Fabian Fonzar R, Carrabba M, Ferrari M. Comparison of Contrast Ratio, Translucency Parameter, and Flexural Strength of Traditional and "Augmented Translucency" Zirconia for CEREC CAD/CAM System. J Esthet Restor Dent. 2016;28(Suppl 1):S32-9.

29. Harada K, Raigrodski AJ, Chung KH, Flinn BD, Dogan S, Mancl LA. A comparative evaluation of the translucency of zirconias and lithium disilicate for monolithic restorations. J Prosthet Dent. 2016 Aug;116(2):257-63.

30. Jurišić S, Jurišić G, Zlatarić DK. In Vitro Evaluation and Comparison of the Translucency of Two Different All-Ceramic Systems. Acta Stomatol Croat. 2015 Sep;49(3):195-203.

31. Arocha MA, Basilio J, Llopis J, Di Bella E, Roig M, Ardu S, et al. Colour stainability of indirect CAD-CAM processed composites vs. conventionally laboratory processed composites after immersion in staining solutions. J Dent. 2014;42(7):831-8.

32. Dayan C, Guven MC, Gencel B, Bural C. A Comparison of the Color Stability of Conventional and CAD/CAM Polymethyl Methacrylate Denture Base Materials. Acta Stomatol Croat. 2019;53(2):158-67.

33. Barizon KT, Bergeron C, Vargas MA, Qian F, Cobb DS, Gratton DG, et al. Ceramic materials for porcelain veneers: part II. Effect of material, shade, and thickness on translucency. J Prosthet Dent. 2014 Oct;112(4):864-70.

34. Paravina RD, Pérez MM, Ghinea R. Acceptability and perceptibility thresholds in dentistry: A comprehensive review of clinical and research applications. J Esthet Restor Dent. 2019 Mar;31(2):103112. 